\title{
SiM
}

\section{Texas GLCl: Growing Partnerships on Texas Grazing Lands}

\author{
By Jeff Goodwin and Mark Moseley
}

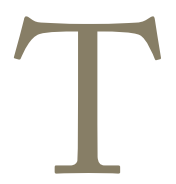

he United States comprises more than 634 million acres of nonfederal grazing lands. Under proper management, these private grazing lands contribute to the health and economic sustainability that the nation has relied on for many years. Private grazing land owners understand the need for continued grazing land technical assistance. Providing a mechanism to attain sound, science-based, proven conservation alternatives to address the nation's grazing land resource concerns is of paramount importance to these land owners. The loss of trained individuals providing technical assistance would be detrimental not only to new grazing land managers but also to established operations that have been using this technical assistance for years to make difficult ranch management decisions. This loss of trained individuals did occur in the past: the loss of USDANatural Resource Conservation Service (NRCS) technical resources on grazing lands was a by-product of the 1985 Farm Bill, which diverted many NRCS employees to cropland conservation compliance and other programs. The Grazing Lands Conservation Initiative (GLCI) was formed in response to this decline in technical assistance on private grazing lands.

\section{GLCI Founding}

The Grazing Lands Conservation Initiative is a coalition of organizations and individuals who support the stewardship of privately owned grazing lands. Borne out of the need to restore NRCS technical grazing land assistance to private landowners, the national GLCI was organized in 1991 in Bozeman, Montana. A like-minded partnership shared concerns about the numerical erosion of NRCS grazing land management specialists available to help nonfederal local landowners.

In Bozeman 22 states were represented. Each of these independent state organizations shared different views on various issues. However, all agreed on one thing: the need to restore grazing land technical assistance for the private landowners of the nation. From that focus sprang the GLCI with nine national organizations sponsoring GLCI's mission. Currently GLCI is led by a steering committee composed of the National Association of Conservation Districts, the National Cattleman's Beef Association, the American Forage and Grassland Council, the American
Sheep Industry, the American Farm Bureau Federation, the Society for Range Management, the Dairy Industry, the Soil and Water Conservation Society, and the National Farmers Union. Most of its members are landowners and producers.

\section{Texas GLCI}

The Texas GLCI Coalition officially organized in 1994 with 40 organizations supporting its goals and mission. These charter members are commonly referred to as the "Founding Forty." The Texas GLCI Coalition is a member of the national GLCI coalition. To accomplish its task, the GLCI works with any partnership that shares this mission.

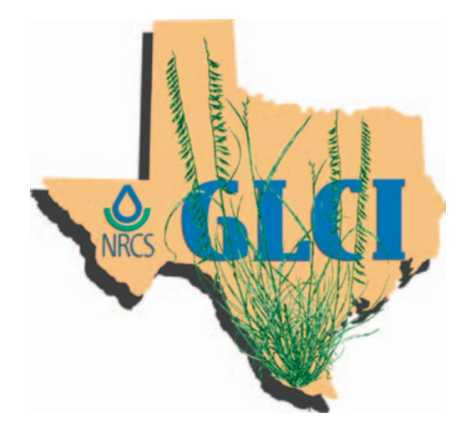

The Texas GLCI Coalition is organized to support efforts that the owners and managers of private grazing lands have available to them. Expert technical assistance is necessary to implement, on a voluntary basis, available technologies for conservation management of the private grazing lands and other natural renewable resources of Texas. To attain success the assistance needs to be coordinated to achieve the desired environmental stewardship involving all uses of the land. Texas is a very ecologically diverse state, with precipitation zones ranging from 50 inches/year in east Texas to 10 inches/year in west Texas. Spatially, rangeland in Texas is the largest grazing land use; however, the intent of GLCI is provide technical assistance to all grazing land managers and grazing land uses. Figure 1 shows the types and extent of grazing land in Texas. 


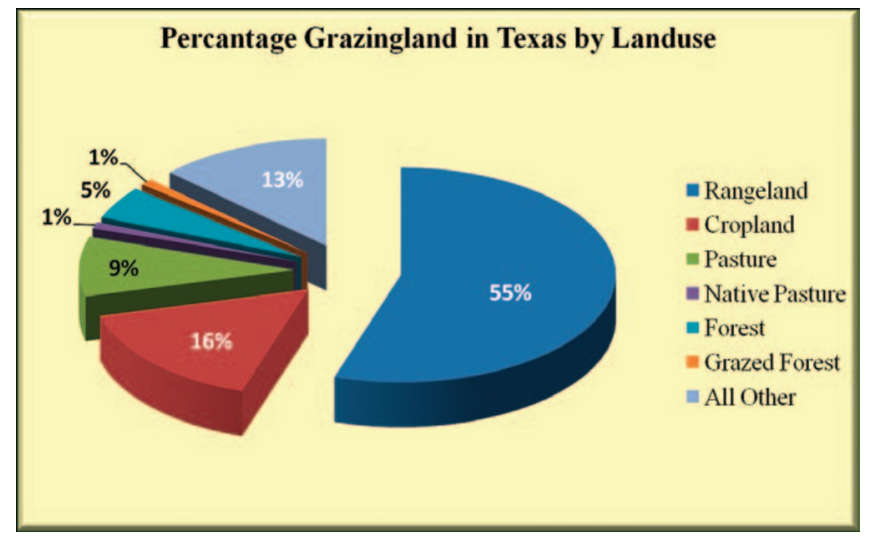

Figure 1. Grazing land in Texas by land use.

\section{The Texas GLCI}

The Texas GLCI was established to provide for the following:

- A coordinated effort to identify priority issues, find solutions, and effect change on privately owned grazing lands

- Leadership and guidance in implementing the GLCI mission

- A basis for coordination with other units of government, institutions of higher learning, and other agencies as appropriate to promote the enhancement of grazing land resources

- Opportunities to increase the information base from which sound policy and resource management decisions are developed and

- Methods to increase the awareness and transfer of technical information to grazing lands producers.

The primary partner of the Texas GLCI is the NRCS, providing trained specialists to work on privately owned grazing lands. Texas GLCI utilizes funding to hire, redirect, or relocate qualified grazing land management specialists. Texas GLCI also secures funding to expedite Ecological Site Description development. Additionally Texas GLCI develops effective information products, including displays, videos, presentations, brochures, booklets, etc., that emphasize grazing land stewardship and inform the public about the value of grazing lands. Last, Texas GLCI is responsible for the development and implementation of a continuing education program for conservation partners, landowners, and industry professionals. The Texas GLCI executive committee determines the conservation focus and direction for the state's educational program.

Rooter Brite, a rancher from Bowie, Texas, is the current chair of the Texas GLCI, and all of the steering committee members are award-winning land stewards. Some of the awards won by Texas Coalition Steering Committee members include the Lone Star Land Steward Award, Excellence in Rangeland Stewardship, Leopold Conservation Award, Regional National Environmental Stewardship Award of the National Cattleman's Beef Association, and Texas Section of Society for Range Management's Outstanding Rangeland Management Award.
As previously stated, one goal of the Texas GLCI is to restore grazing lands-trained employees to work with land managers in the field. Another is to address needed changes in the policies and programs of the USDA to help address this issue. Much of this communication is accomplished by individual GLCI steering committee members making legislative visits. Table 1 illustrates the staffing history of NRCS Rangeland Management Specialists for Texas since 1969.

Approximately 250 employees each year spend more than $50 \%$ of their time on grazing lands. Leadership is the key to Texas GLCI's successes. Support from the NRCS State Conservationists and his or her staff has been critical. Not only have the State Conservationists worked to provide funding support for the GLCI efforts, but staffing of field specialists has increased.

In addition to the NRCS providing a State GLCI Grazing Land Specialist, the Texas GLCI is also subdivided into 10 regions (Fig. 2). Each region has its own local grazing land specialist, advisory board, regional conservation focus, and independent projects.

An excellent example of successful Texas GLCI leadership is the Coastal Prairies Conservation Initiative (CPCI). The CPCI is a major cooperative effort between partners such as Fish and Wildlife Service, Texas Parks and Wildlife Service, The Nature Conservancy, Coastal Prairies GLCI, Natural Resources Conservation Service, and the Sam Houston Resource Conservation and Development Council. The Coastal Prairies GLCI has remained in the leadership role for the CPCI, which encouraged the participation of local ranchers. This endeavor, initiated in 1995, had a mission to restore native coastal prairies. Addition-

\section{Table 1. Staffing history of NRCS Rangeland Management Specialists in Texas}

\begin{tabular}{|c|c|c|c|}
\hline Year & $\begin{array}{l}\text { Rangeland } \\
\text { manage- } \\
\text { ment } \\
\text { specialists }\end{array}$ & $\begin{array}{l}\text { Permanent } \\
\text { full-time } \\
\text { employees }\end{array}$ & $\begin{array}{l}\text { Percent } \\
\text { of work- } \\
\text { force }\end{array}$ \\
\hline 1969 & 60 & 1,363 & 4.4 \\
\hline 1974 & 73 & 1,237 & 5.9 \\
\hline 1980 & 108 & 1,187 & 9.1 \\
\hline 1985 & 99 & 1,042 & 9.5 \\
\hline 1998 & 44 & 711 & 6.2 \\
\hline 2009 & 72 & 760 & 9.5 \\
\hline 2010 & 81 & 791 & 10.2 \\
\hline 2011 & 70 & 739 & 9.5 \\
\hline
\end{tabular}




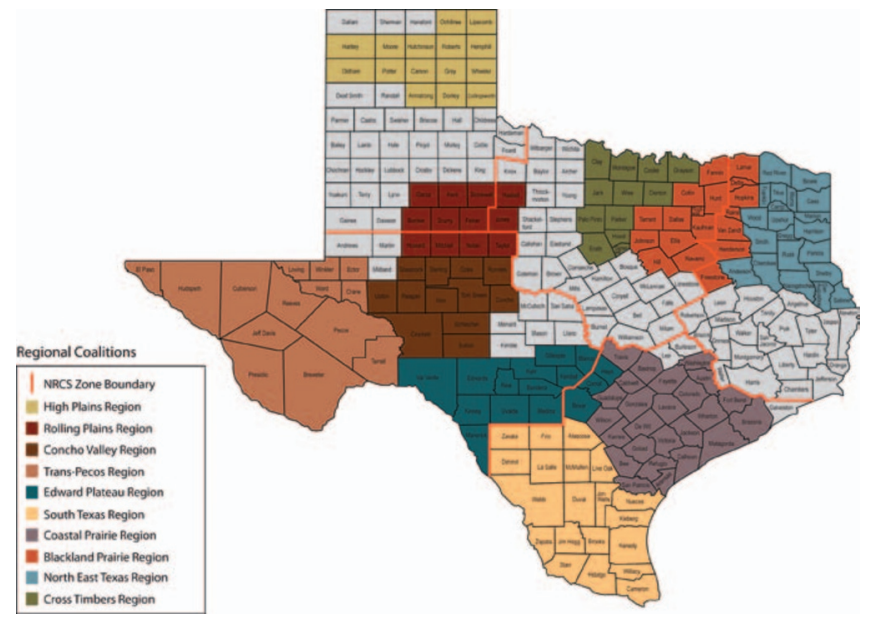

Figure 2. Texas GLCl regional structure.

ally, a goal was to reintroduce the endangered Attwater's prairie chickens back onto the prairie. The Attwater's prairie chicken is arguably one of the most endangered birds in the nation, with less than $1 \%$ of its historical habitat remaining. The bird had disappeared from this area for reasons not fully understood. After several years of cooperative prairie restoration by private landowners, there was a first ever release of the bird back onto private lands. A key element in this effort is that the Coastal Prairies GLCI is the holder of the Safe Harbor Agreement for the local ranchers. The first release of Attwater's prairie chickens occurred in the summer of 2007 (Fig. 3).

The primary ability and cornerstone of Texas GLCI is providing grazing land technical assistance to private landowners. Over the past year, Texas GLCI has been very successful in providing that technical assistance to grazing land owners and operators. In fiscal year 2011, through the efforts of 11 grazing land specialists, grazing land conservation planning and technical assistance was provided to 395 landowners and/ or operators on 2,792,018 acres of private grazing land. The average operating unit was 14,370 acres. This grazing land technical assistance is directed at addressing specific resource concerns, within the NRCS conservation planning procedure. These conservation plans meet resource concerns by planning specific conservation practices, including prescribed grazing, prescribed burning, brush management, range planting, forage and biomass planting, forage harvest management, nutrient and pest management, livestock water development, etc.

The Texas GLCI is allocated annual funding to support its activities by the NRCS State Conservationist. This is done through a 50-50 contribution agreement. Partners contribute their 50 percent of the cost through financial and in-kind contributions. In addition to several publications, producer grants, and training events for NRCS employees and partners, GLCI uses these funds to sponsor speakers' fees and supporting publications and other expenses related to conducting tours, field days, and training events. Texas GLCI grazing land specialists provided grazing land training and technology transfer to more than 915 NRCS personnel and conservation partners in FY
2011. Under Texas GLCI's 2011 outreach and education mission, 124 technical presentations on grazing land topics were given to 8,363 participants, of which 5,432 were grazing land owners and/or operators. This was accomplished in partnership with 313 cooperating organizations.

One of the major educational focal points of Texas GLCI recently has been ranch economics. With the ever rising input costs faced by Texas ranchers, the industry is consistently looking for viable alternatives to traditional methodologies. In an effort to address these concerns, Texas GLCI has provided leadership by harnessing the power of partnerships through educational workshops across the state on topics ranging from ranch profitability, ranch economics, and holistic management to overall grazing management strategies and animal behavior.

In Texas, 2011 was the driest year in the Texas historical record, accompanied with a record-setting wildfire season. Texas GLCI provided numerous drought management and wildfire recovery workshops and field tours across the state. Addressing the many issues facing the state's grazing land owners, the workshops focus on post-drought grazing management strategies, destocking strategies, drought management planning, wildfire prevention and mitigation, etc. In an effort to promote prescribed burning as a wildfire mitigation tool, Texas GLCI has developed a video targeting local county officials: Prescribed Fire: A Historical Tool With New Opportunities (Fig. 4). The video is approximately $10 \mathrm{~min}-$ utes in length and is well designed to be presented at County Commissioner meetings, etc. The video provides insight and comments from Tom Boggus (Texas Forest Service Director), County Judges, County Commissioners, County Attorneys, and ranchers, all of whom have successfully applied prescribed fire in their counties under burn bans. The intent of the video is to provide insight and outreach to local county officials regarding the use of prescribed burning as a natural resource management and wildfire mitigation tool.

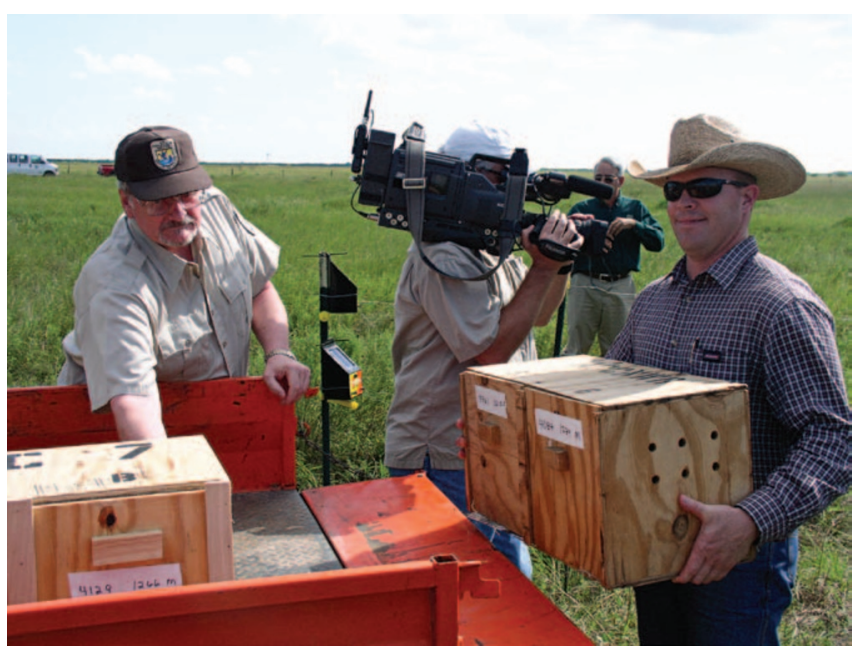

Figure 3. Coastal Prairie GLCl Chairman Stephen Diebel working with US Fish and Wildlife personnel releasing Attwater's prairie chickens in the coastal bend of Texas. 


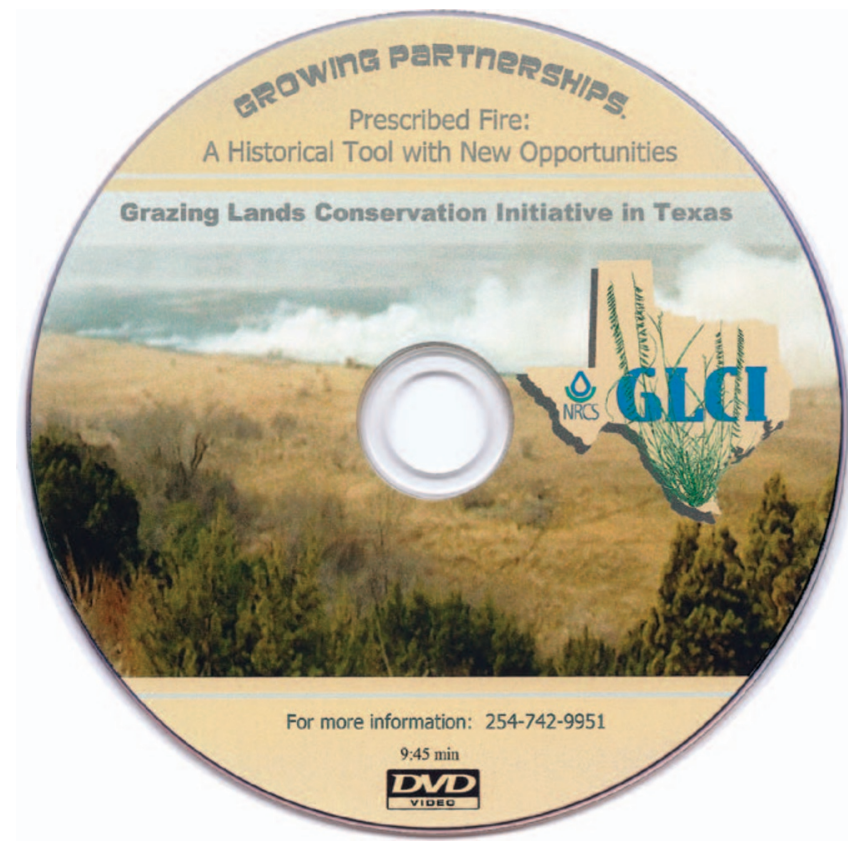

Figure 4. Prescribed Fire: A Historical Tool With New Opportunities.

Texas GLCI is also very involved with representing the conservation practices it recommends through field trials and demonstrations. Texas GLCI has currently initiated $32 \mathrm{ac}-$ tive research and demonstration sites across this state with 46 different operating units investigating wildfire effects on rangeland, including soil quality dynamics in relation to conventional grazing land management techniques, effects of management on ecological site description changes, and dormant season forage quality dynamics. All of these have been done with partners too numerous to mention.

\section{Building Soil Health with Grazing Management}

Healthy soils are paramount to the future of the Texas grazing lands by maintaining ecosystem function and sustaining plant communities. Mismanagement of Texas' soil resources has lead to physical soil loss via erosion and a large decline in

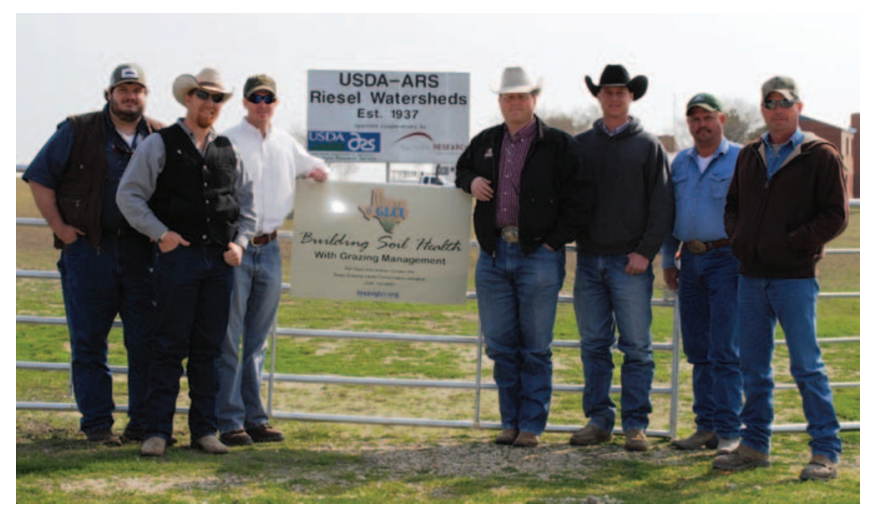

Figure 5. Texas Soil Health Partnership. soil organic matter. Texas GLCI has entered into a partnership with the USDA-Agricultural Research Service (ARS), NRCS, and Texas Agrilife Research to investigate the opportunities of building soil health with grazing management (Fig. 5). ARS provided the Riesel Watersheds, an 840-acre facility, for all primary demonstration projects and all field outreach and education events.

The intent of this project is to quantify and demonstrate that managing for soil health can provide economically feasible and ecologically viable alternatives through increasing soil biological activity, reducing forage deficiencies in grazing strategies, and reducing or eliminating inorganic inputs through the implementation of innovative conservation management practices and systems. This long-term project is Texas GLCI's newest partnership and has the potential of providing significant production and economic data for many years. Through this project the partnership proposes to meet the following management objectives:

1) Improve soil health biologically, physically, and chemically through the implementation of innovative conservation and management strategies

2) Compare conventional approaches and cultural practices to nontraditional conservation systems focused on addressing identified resource concerns and management of soil health and

3) Conduct technology transfer targeting private landowners.

The overriding intent of this project is to highlight innovative management strategies that focus on soil health through systems that optimize vegetation/forage production, benefit livestock production, promote water quality, and optimize energy savings, benefiting landowners and society through the economic and ecological sustainability of the agricultural enterprise.

\section{Conclusion}

Texas GLCI has been a conservation leader promoting grazing land stewardship in Texas for 18 years. Over that 18-year span, Texas GLCI has held its technical integrity and established itself as a proven facilitator, bringing partners together for sound science-based grazing land conservation information and technical assistance. Though Texas GLCI has many accomplishments, none of those would have been possible without the strong grassroots leadership of the Texas GLCI executive committee and its partnerships, specifically its partnership with the NRCS. As Texas GLCI moves into the next 18 years, the trust and partnerships developed through hard work, perseverance, and technical integrity will ensure that grazing land stewardship will continue into the future.

Authors are State GLCI Grazingland Specialist, USDA-NRCS, Temple, TX 76501, USA, jeff.goodwin@tx.usda.gov (Goodwin); and Ecological Site Inventory Specialist, USDA-NRCS, Boerne, TX 78006, USA (Moseley). 